\title{
MODERN METHODS OF ELIMINATION OF LOST CIRCULATION IN DIRECTIONAL WELLS
}

\author{
Tatiana N. IVANOVA \\ Tchaikovsky Branch "Perm National Research Polytechnic Institute" \\ Federal State Budgetary Institution of Science \\ "Udmurt Federal Research Center of the Ural Branch of the Russian Academy of Sciences", \\ Institute of Mechanics \\ Iwona ŻABIŃSKA \\ Silesian University of Technology
}

\begin{abstract}
:
Losses of drilling mud and other fluids is the one of the major types of drilling troubles. Annual time losses for their elimination by oil and gas companies are huge. The factors, influencing the mud losses and regulating the direction of the further works, can be divided into two groups: geological and technological. Conducted studies on the use of an insulating composition based on chromium acetate made it possible to identify: the use of the insulation composition on the chrome acetate base allows considerable reduction of time required to eliminate disastrous circulation loss without installation of cement plugs; avoiding BHA replacement; avoiding drilling-in after bullheading and overlapping of lost-circulation layer; low cost, possibility of fast preparation, as it does not entail the delivery of additional chemicals, which also contributes to reduction of time required to eliminate disastrous circulation loss; the use with every type of drilling mud. Basing on the positive experience of the use of this composition in the neighboring regions and considering its economic side, the technique can be used in regions of the Udmurt Republic.
\end{abstract}

Key words: liquidation of acquisitions, drilling tool run-in-hole/put-out-of-hole, restoration of circulation, drilling process, lowering or cementing of the production casing

\section{INTRODUCTION}

Losses of drilling mud and other fluids is the one of the major types of drilling troubles. Annual time losses for their elimination by oil and gas companies are huge. However, the losses turn out to be considerably higher, if one takes into account that cement slurry losses result into lower cement height than the designed one and, consequently, workover works are required. During flow stimulation after workover as well as primary flow simulation the permeability of productive strata decreases, other drawbacks may occur. Therefore, an improvement of methods and means to eliminate the losses of drilling mud and other fluids is a way to reduce the cycle of well construction.

The losses of drilling mud in wells are determined by permeability, porosity, reservoir pressure, reservoir strength, volume of pumped drilling fluid and its quality.

When the pressure in a wellbore exceeds the pressure of the bed, penetrated during drilling, the mud will enter the pores, channels and rock fractures, overcoming local hydraulic resistance. A decrease in the pressure in a wellbore relatively to the reservoir pressure results in the penetration of the mud from the bed to the well, i.e. water, oil and gas showings. Thus, one and the same stratum can be lost-circulation layer or inflow one.

Occurrence of fluid losses also depends on drilling method and drilling technique. Mechanical action (smashes, vibrations) of the drilling tool on the borehole walls or high excessive pressure can cause drilling mud absorption by the previously isolated horizons, or the horizons, which were not found during penetration.

Depending on the thickness and the strength of dense area of a rock or cement stone, the value and cyclicity of the loads applied, the destruction can happen in different moments: during drilling tool run-in-hole/put-out-of-hole (RIP/POOH), restoration of circulation, drilling process, lowering or cementing of the production casing. 
Other technical and technological causes, contributing to formation of drilling mud losses, include all the factors, which result into the growth of the pressure in the annulus space in the process of well flushing. The phenomenon of mud loss is connected with penetrating the permeable or (and) weak strata during well drilling and involves the movement of drilling mud or cement slurry from the well inside the stratum under an action of excessive hydrostatic (or hydrodynamic) pressure (in comparison with reservoir pressure), which is formed in the well in the process of drilling.

\section{LOSSES OF DRILLING FLUIDS AND GROUTING COMPOSI- TIONS DURING DRILLING AND WELL CASING. LITERA- TURE REVIEW}

There are several definitions of the term "fluid loss" [129]:

- fluid loss is the penetration of drilling mud of grouting composition in a bed in a such volume, which exceeds natural shrinkage of fluid in a well;

- fluid loss represents the imbalance between the pressure of the fluid in a well on a layer $p_{\text {st }}$ and the reservoir pressure in a permeable rock (reservoir) $p_{\text {res, }}$ which causes the movement of technical fluid in the layer, when $p_{\text {st }}>p_{\text {res; }}$

- losses of drilling mud and grouting compositions during well construction - is a complication occurring due to an excess of well pressure over the reservoir pressure and the presence of open and interconnected channels in a layer;

- consequence of fluid loss include full or partial loss of circulation of drilling fluid and grouting composition in the process of drilling, well flushing or well casing.

Fluid loss occurs only when hydrostatic pressure in a well or the sum of hydrostatic and hydrodynamic pressure exceeds an ultimate value of pressure, under which a stratum starts to absorb drilling mud or grouting composition. This can happen during performance of different technological operations: restoration of circulation, wellbore reaming, drilling, and casing. The fluid losses can be caused by an excess of mud density over the calculated value. In this case, the ratio of well pressure to reservoir pressure changes. The stratum is exposed to the pressure, developed by the well. This pressure is equal to hydrostatic pressure of drilling mud column:

$$
p_{\text {st }}=\rho_{\text {liq }} \cdot g H \text {, }
$$

In the process of drilling mud circulation, a layer is exposed to the sum of pressure values - besides hydrostatic pressure $p_{\text {st }}$, hydrodynamic pressure $p_{\text {hyd }}$ is added. Hydrodynamic pressure is necessary to overcome hydraulic resistance during movement of fluid in the annular space of a well at the length $H$.

The pressure of a fluid in a layer $p_{\text {res }}$ depends on conditions of formation of productive horizon. The reservoir pressure is assessed by fluid column $H$, which is set in a stopped well:

$$
p_{\text {res }}=\rho_{\text {liq }} \cdot g H \text {, }
$$

when $p_{\text {res }}>p_{\text {st, }}$ showings occur - fluid from the reservoir enters wellbore and goes to the surface.

When $p_{\text {res }}<p_{\text {st }}$ (in case of circulation loss) fluid losses occur - the fluid from the wellbore penetrates into the layer. In case of the presence of circulation in a well, fluid losses occur under the next interrelation of pressure values:

where:

$$
p_{\text {st }}+p_{\text {hyd }}=\rho_{\text {res }}+p_{\text {hr }} \text {, }
$$

$p_{\mathrm{hr}}$ - pressure loss on hydraulic resistance during movement of drilling mud in the channels of the layer, MPa.

The signs of losses of drilling mud and grouting compositions can be divided into direct and indirect ones. In case of the mud loss, the flow rate at the outlet of the well is lower than at the inlet, the fluid level in mud pits decreases. However, these direct signs of fluid losses can be not so apparent if the oil showings occur simultaneously with the losses. During drilling of lost-circulation intervals indirect signs of mud loss also can be distinguished. They include tool failures and an increase in rate of penetration (ROP), worsening of cuttings removal, local accumulations of cuttings in the wellbore, followed by jamming and stalling of the tool in places of cuttings accumulation. Indirect signs of interlayer flows also include a change in density of drilling mud and its properties as well as ion composition. In highly fractured reservoirs the grouting composition can be absorbed with solid phase. A decrease in pressure for squeezing of grouting composition is the sign of such hydrodynamic interaction $[1,2,3,4,5,6,7,8$, $9,10,11,12,13]$.

In case of absorption, drilling mud becomes oversaturated with slurry. Slurry settling is formed at the bottomhole, local accumulations of cuttings are also accumulated above the bottom. They lead to packing, dragging and jamming of the drilling tool. Due to a decrease in back pressure sloughing and caving of walls of a well may develop, gas, water and oil showings can occur. At the same time, consumption of drilling mud, materials and chemicals increases, while ROP drops [14, 15, 16, 17, 18, 19, 29]. The study of the lost-circulation zones is carried out using special well surveys, performed by the drilling company on the instruments available on the drilling rig. This is an operational type of control. In addition to the operational type of control, special types of research are used - fieldgeophysical (caliper measuring, all types of logging, resistivity metering) and hydrodynamic (fall-off and build-up tests, study of lost-circulation formations using a packer) $[20,21,22,23,24,25,26,27,28]$.

The practice shows that the implementation of the measures considered solves many issues on the prevention and elimination of fluid losses, reducing their number or decreasing their intensity to $50-90 \%$.

\section{THE CAUSES OF THE FLUID LOSSES AND THE METHODS TO STUDY A LOST-CIRCULATION STRATUM. RESEARCH METHODOLOGY.}

The factors, influencing the mud losses and regulating the direction of the further works, can be divided into two groups. 
1. Geological factors - type of lost-circulation stratum, its thickness and occurrence depth, insufficient resistance of rocks to rupture, the value of reservoir pressure and reservoir fluid properties.

2. Technological factors - The quality and the amount of drilling mud applied to the well, drilling method, the speed of RIP/POOH operations.

The fluid losses begin under the condition that penetrated layers have sufficiently high hydraulic conductivity and the pressure difference between a wellbore and lost-circulation bed is higher than critical value.

In case of insufficient resistance of rocks the fracturing process occurs.

Geophysical survey methods for studying of lost-circulation layers. Geophysical-field methods include measurements of parameters with electric level meter, resistivity meter, caliper logging tool as well as micro logging, electric logging, radioactive and acoustic logging, depth imaging, depth (borehole) television. The diagrams of radioactive and acoustic logging are used as additional means for specifying the boundaries of lost-circulation layers. The data of geophysical-field surveys help to study the changes in the properties of lost-circulation layers along the area. Radioactive logging diagrams are used for velocity layering, strata correlation, tracing of changes in lithology and porosity of rocks of the lost-circulation horizon. Acoustic logging diagrams ensure clear localizing of vugular and fractured rocks due to a sudden decrease in the velocity and an increase of consumption of energy from elastic oscillations.

For visual demonstration of the results of the survey the joint scheme of fluid losses is built for each area. This practice has found wide use during well drilling in Saratov and Volgograd trans-Volga regions. Every lost-circulation layer is marked on diagrams of gamma-logging (GL) and neutron-gamma-logging (NGL), recorded in the same well. Then, having carried out the correlation, the same layers are identified on a typical section of the given area and identification symbols are written near them in a separate column. At the same time, they write down the data including the type of formation according to the classification, the static fluid level in the well according to the measurement data and in terms of clean water, as well as any other information, reflecting the characteristics of the lost-circulation formation.

The boundaries of the thief zone, established with a flow meter, illustrate the most permeable part of it, for which the presence of big fractures and large interconnected vugs is typical. In general, it complies with the results of comparing the values of the thief zones, determined using the flow meter and geophysical surveys.

In most cases, lost-circulation intervals are found on $\mathrm{GL}$ and NGL diagrams by a decrease in intensity of secondary gamma-radiation and apparent resistivity. It is also necessary to pay attention to studying of the slurry, as the results of its analysis are often vital for establishment of lost-circulation layers characteristics.

Tracking the decrease of well fluid level (pressure). The borehole is filled by the fluid to the wellhead, then fluid injection is stopped and the time for level to decrease by each 5 or $10 \mathrm{~m}$ is measured. The measuring lasts until the balance state is reached in the well, i.e. until the well fluid level reaches static position. The decrease in the level in the well over time is measured by level meter or it can be recorded by means of downhole pressure gauge in the form of a pressure - time curve.

Tracking the rise of the level in the drill pipes after an "instant" decrease. An "instant" decrease of the level in a well is reached by lowering of drill pipe string, equipped with end plug, which is further destroyed, causing the fluid from the annulus to move into drill pipes. As a result, a rapid equalization of the fluid in the pipes and the annulus occurs. The fluid level in the well is reduced by the value, which corresponds to fluid volume, displaced by the string of drill pipes with the closed end (non-steady flow). The pressure build-up, caused by a fluid flow from the lost-circulation horizon is recorded by tracking the rise of the level in the drill pipes with the use of flow meter or a downhole pressure gauge, registering the pressure-time curve.

Tracking the rise of the level in the drill pipes after an "instant" decrease given the wellhead is hermetically sealed. This method is fulfilled the same way as the previous one, the only difference is that the wellhead is hermetically sealed with a blowout preventer or a packer to prevent from fluid overflow. As the rise of the level in the drill pipes can be tracked only before reaching the wellhead, the initial sector of the indicator line is obtained by extrapolation. This method has the same drawbacks as the previous one. The following methods have found widest use for studying of lost-circulation layers: tracking the decrease of well fluid level (pressure), fall-off and build-up tests. Pressure transient testing is recommended to use if the time of pressure build-up exceeds 30 minutes. In this case the error for the specific injectivity coefficient, calculated according to the formulas for steady mode, does not exceed tool accuracy (7-10\%). As for lower values of pressure build-up time, the steady-state flow research methods should be applied or it is necessary to introduce correction factors.

The losses of circulation fluid during well construction in Udmurtia mostly occur in Upper Permian, Serpukhovian and Okskian deposits.

Upper Permian system is characterized by terrigenous deposits, absorption intensity of which reaches up to 45 $\mathrm{m}^{3}$ /hour. As for Serpukhovian - Okskian reservoir, carbon fractured deposits are typical, where the fluid losses range from $25 \mathrm{~m}^{3} /$ hour to full absorption.

Insignificant fluid losses (up to 3-5 $\mathrm{m}^{3}$ /hour) are encountered in case of penetration the Upper Carboniferous deposits.

\section{EXPERIENCE IN ELIMINATION OF FLUID LOSSES Republic of Bashkortostan}

The geological conditions of this region are complicated by the presence of very thick layers which absorb the mud with medium or dramatical intensity during drilling. What 
is more, drilling of wells in the upper intervals often encounters the interlayers, which start flowing with reservoir water of high hydrogen sulfide content.

During the construction of well № 926Г on Spasskoe field belonging to Bashneft-Drilling LLC, the drilling mud loss has begun at the depth of $1150 \mathrm{~m}$, with the intensity exceeding $30 \mathrm{~m}^{3} /$ hour. It was also complicated by the reservoir water inflow with a high $\mathrm{H}_{2} \mathrm{~S}$ content and a density being $1.06 \mathrm{~g} / \mathrm{cm}^{3}$ (Upper Carboniferous 522-769 m). These all resulted in the incompatible drilling conditions. The use of standard methods (the application of viscoelastic compositions, gel-cements and etc.) during well construction has not brought the required results or has shown a short-term effect. The total losses of drilling mud reached $543 \mathrm{~m}^{3}$. The total volume of packing clay/gel-cement/crumb rubber filler/sawdust was $337 \mathrm{~m}^{3}$. The time required to eliminate the trouble accounted 41 day.

In order to eliminate the trouble, five cubic meters of "QUICK-STONE ${ }^{\mathrm{TM}}$ composition with density $1560 \mathrm{~kg} / \mathrm{m}^{3}$ has been injected. As a result of application of this technique, the intensity of the fluid losses has been reduced from full absorption to $1-2 \mathrm{~m}^{3}$ /hour.

Only 6 hours has been spent for the system installation and waiting-on-cement (WOC). In comparison with the classical installation of a cement plug, the holding time for the cement hardening has been reduced by 21 hours.

\section{Perm Krai}

During the process of drilling of well № 314 of Trifonovskoe field three fluid losses have been recorded. The first fluid loss occurred on the third day of well construction at the depth of $50 \mathrm{~m}$ during surface casing drilling. To eliminate the trouble, the drilling was continued despite fluid loss, the surface casing with diameter of $426 \mathrm{~mm}$ was lowered and cemented by topup cementing method

The second fluid loss (full absorption) happened on the $4^{\text {th }}$ day of well construction, when the bottom depth was 73 $\mathrm{m}$. The cement plugging (casing string $-47 \mathrm{~m}$, portland cement -6 tons) failed. The cement plug was not encountered, full absorption occurred. Further drilling resulted in the partial recovering of circulation at the depth of $77 \mathrm{~m}$. Then, by reaching $90 \mathrm{~m}$, full absorption of drilling fluid occurred again. The drilling was continued without returns of circulation (with stops to collect technical water). Then the conductor with diameter of $324 \mathrm{~mm}$ was lowered to the depth of $111 \mathrm{~m}$ and top-up cementing was fulfilled. (The setting depth of the $324 \mathrm{~mm}$ conductor was changed from 70 to $110 \mathrm{~m}$ due to the drilling experience of previous wells.

The third fluid loss happened on the $10^{\text {th }}$ day of well drilling at the depth of $321 \mathrm{~m}$. On the base of experience of previous drilling, fluid loss prevention measures were taken at depth of $280 \mathrm{~m}$. The cement plug (portland cement - 6 tons) had been installed at the interval between $249-282 \mathrm{~m}$, before the technical string with the diameter of $245 \mathrm{~mm}$ was lowered and fastened, in order to provide the sufficient cement height and ensure pumping the full cement volume during cementing. It was found out that the most efficient (both according to the quality and to required time losses) method of elimination of fluid losses is top-up cementing of strings with setting of a cement basket above the lost-circulation interval. As for the least efficient method, it is the cement plugging on the base of foam cement, which did not help to eliminate the fluid losses in the cases, when the method was applied.

\section{Yamalo-Nenets Autonomous Okrug (YaNAO)}

In field conditions this insulation composition has showed itself from the good side. During drilling of well № 8835 in the Urengoyskoye field of YaNAO the full stop of circulation occurred by reaching the depth of $2847.6 \mathrm{~m}$. To eliminate the fluid loss an insulation-sealing composition on the base of chrome acetate was used in the volume of $4 \mathrm{~m}^{3}$.

After the pumping of the composition and return of the part of it into the open borehole $\left(1.5 \mathrm{~m}^{3}\right.$ of the total volume of the pack, which was $4 \mathrm{~m}^{3}$ ), a circulation return was noted. The pumping was continued according to the plan of works, i.e. the remaining $2.5 \mathrm{~m}^{3}$ were pumped when circulation return reached $85-95 \%$ from the volume, pumped in the well. Further, the tool was lifted above the interval of setting of the insulating composition, which was followed by pressing the composition into the lostcirculation formation with a step-up increase in the flow rate of the drilling fluid. Then, the technical settling was fulfilled and the tool was lowered. After this, bottomhole flushing was carried out, circulation return was full, fluid losses were absent. The drilling process was continued in the normal mode.

\section{CHARACTERISTICS OF CONSIDERED METHODS AND THEIR ECONOMIC ANALYSIS}

The losses of drilling mud and other fluids are the one of the major types of drilling troubles. Annual time losses for their elimination by oil and gas companies are huge. However, the losses turn out to be considerably higher, if one takes into account that cement slurry losses result into lower cement height than the designed one and, consequently, workover works are required. During flow stimulation after workover as well as primary flow simulation the permeability of productive strata decreases, other drawbacks may occur. Therefore, an improvement of methods and means to eliminate the losses of drilling mud and other fluids is a way to reduce the cycle of well construction.

The methodology for selection of measures to avoid and eliminate the fluid losses is based on quantity criteria, showing geological structure and hydrodynamic properties of layers.

Circulation fluid losses during well construction mostly occur in Upper Permian, Serpukhovian and Okskian deposits.

Upper Permian system is characterized by terrigenous deposits, absorption intensity of which reaches up to $45 \mathrm{~m}^{3} /$ hour. As for Serpukhovian-Okskian reservoir, 
carbon fractured deposits are typical, where the fluid losses range from $25 \mathrm{~m}^{3} /$ hour to full absorption. Insignificant fluid losses (up to 3-5 $\mathrm{m}^{3} /$ hour) are encountered in case of penetrating the Upper Carboniferous deposits.

\section{CHARACTERISTICS OF CONSIDERED METHODS}

Elimination of the fluid losses by means of cement plugging

One of the methods of fluid losses elimination is cement plugging with further drilling-in. The installation of cement plugs ensures creation of reliable water-gas-oilresistant cement sleeve with specified strength, strengthening vulnerable vugular part of a borehole and elimination of the fluid losses.

For the installation of cement plugs with the purpose of sealing of lost-circulation intervals, different grouting mixtures on the base of binding materials, polymers, and clay are used. In common, they are prepared on the surface and then delivered to the thief zone through the drill string or the wellbore. To achieve a given interval by the grouting mixture, its plastic strength, thickening time and setting time should be easily adjusted to specific geological and technical conditions. To prevent the grouting mixture from thickening during its movement to the lost-circulation interval, at least 10-15 minutes must pass before the start of its setting after the end of pushing into the formation. The grouting mixture must be resistant to dilution with drilling mud or reservoir water. It is also necessary that it should rapidly build up its structural and mechanical properties after being pushed into the lost-circulation formation. The cement stone compression strength should exceed 0.5-1 MPa after 8-16 hours of hardening and be resistant to the action of reservoir water, temperature and pressure. Field data demonstrate that cement plugs are often unsealed and characterized by the low strength due to partial or complete washing out of grouting mixture during the its installation and cement setting. That is why the insulation works and the properties of grouting mixtures should meet certain requirements

Firstly, prepared grouting mixture should be pumped from the surface to the thief zone through drill pipes along the wellbore. Secondly, it should provide a rapid growth of strength of cement stone and reliable sealing of thief zone channels. Thirdly, structural and mechanical properties of grouting mixture as well as its setting time should be regulated.

\section{Conclusion}

1) Installation of a cement plug entails drilling-in, which considerably increases the time to eliminate the disastrous circulation loss.

2) It is necessary to replace bottom-hole assembly (BHA).

3) There is no possibility to use this method in the productive layer.

4) Additional processing of the drilling mud requires additional expenses.
Elimination of circulation losses by means of QUICKSTONE'M technology

Another technique for the elimination of circulation losses is QUICK-STONE ${ }^{\mathrm{TM}}$ composition, which is organomineral compound, consisting of finely dispersed powders with grain size up to 7 microns. The density of the system changes in the range between 1.25 and $2.15 \mathrm{~g} / \mathrm{cm}^{3}$. When the system is in its initial state, it has viscosity, similar to water, and it is characterized by a rapid yet controlled strength growth. Unlike standard cement mixtures, which cannot be pumped through the drill bit, the composition for the creation of the system has the ability to fully dissolve in the hydrochloric acid. Therefore this composition can be pumped through the BHA. The recommended pumping volume of the composition is 5$10 \mathrm{~m}^{3}$.

\section{Application}

A technology for the elimination of circulation losses QUICK-STONE ${ }^{\mathrm{TM}}$ can be used for the next operations during drilling: for solution of the problem of productive layer damage; for the elimination of disastrous fluid losses; for the isolation of zones with oil, water, gas showings; for the temporary well killing; for cement plugging for sidetracking; for the alternative to packer; for consolidation of loose rocks.

\section{Technology}

During QUICK-STONE ${ }^{\mathrm{TM}}$ hardening an exothermic reaction occurs (big amount of heat is generated). This may be due to the increased temperature in the formation, which accelerates the time of the strength buildup of the composition. Other factors (hydrostatic pressure, for example) do not influence the time of the strength buildup. Within a few minutes, the composition shifts from the liquid state to a hard state, which blocks the channels from the movement of gas, water or oil. The compression strength of this composition can be increased to 10000 pounds/square inch (69 MPa), if necessary. Although this composition has high strength, it is easily drilled. The composition includes the following components: magnesium oxide, heptahydrate magnesium sulfate, water, sodium hexametaphosphate, nitrilotrimethylphosphonic acid

The damage of the productive layer during drilling and workover works can lead to a considerable loss of hydrocarbons or the necessity to fulfill the expensive recovery works, such as hydrofracturing, acid treatment of the layer. There are many documentary proofs of formation damage caused by cement works, drilling fluids, etc. In other words, every drilling mud damages the layer to a certain degree. If the rate of filtrate setting is equal to the speed of erosion in dynamic state, the fluid enters the layer. The use of QUICK-STONE ${ }^{\mathrm{TM}}$ technology allows us to solve this problem. After the setting of the composition, it creates impermeable layer, which prevents from precipitation of the drilling mud filtrate. 
When the QUICK-STONE ${ }^{\mathrm{TM}}$ composition is selected, the required setting time and compression strength can be adjusted by means of addition of inhibitors. The composition is completely solved in $15 \%$ solution of hydrochloric acid, which excludes layer contamination in comparison with usual cement.

\section{Conclusion}

1) The use of the composition allows considerable reduction of time required to eliminate disastrous circulation loss without installation of cement plugs.

2) It is not necessary to replace BHA.

3) Complete solubility in hydrochloric acid excludes the contamination of strata in comparison with common cement.

\section{Elimination of fluid losses by means of insulation-sealing composition on the base of chrome acetate}

Chrome acetate is used as a stitcher for water-polymer systems to increase oil recovery from the layers, levelling of injectivity profile of injection wells and remedial cementing. It is compatible with the most of used gelling agents (on the base of polyacrylamides, polysaccharides). Chrome acetate contributes to formation of strong elastic gels. Varying the concentration, one can control the rate and dynamics of stitching. Insulating composition on the base of chrome acetate is the water-based composition, including different fractional fillers, sealants as well as biodegradable polymers with addition of chrome acetate. Application.

This insulation composition is used during drilling to eliminate disastrous fluid losses at any interval of the borehole (can be used in productive layer, as well).

Technology.

The preparation of the insulation composition is made in one of the tanks of mud-mixing unit and does not require employment of additional machinery. Only grout injection aggregate TSA 320 is used for pumping. The composition is easily pumped through circulation sub, which is a component of BHA with telesystem, i.e. it does not require $\mathrm{BHA}$ replacement and time losses on additional pull-out of the drilling tool. The squeezing of this composition in the lost-circulation zone is made with drilling mud, injected by TSA 320 . Then, well flushing is started from stepped increase of flow rate of circulation fluid on drilling pump, it will ensure bullheading of insulation composition in the thief zone. Terminal reaction (stitching of solid phase in the solution) occurs after 4-6 hours. If the reservoir temperature exceeds 60 degree, the time of reaction is 4 hours. The composition allows regulation of setting time by adding sufficient concentration of chrome acetate.

The recommended pumping volume of the composition is 4-8 $\mathrm{m}^{3}$. The composition consists of water, caustic soda, heteropolysaccharide, finely ground marble, phlogopite mica fillers, organic bridging agent, bentonite powder (Fig. 1).
The insulation composition after 4 hours of reaction under the conditions, close to the well and the temperature of 58 degree is demonstrated on Fig. 2.

\section{Conclusion}

1) The use of the insulation composition on the chrome acetate base allows considerable reduction of time required to eliminate disastrous circulation loss without installation of cement plugs.

2) It is not necessary to replace BHA.

3) It does not require drilling-in after bullheading and overlapping of lost-circulation layer.

4) Low cost, possibility of fast preparation, as it does not entail the delivery of additional chemicals, which also contributes to reduction of time required to eliminate disastrous circulation loss.

5) Compatibility with every type of drilling mud (hydrocarbon-base mud (HBM), water-base mud (WBM)).

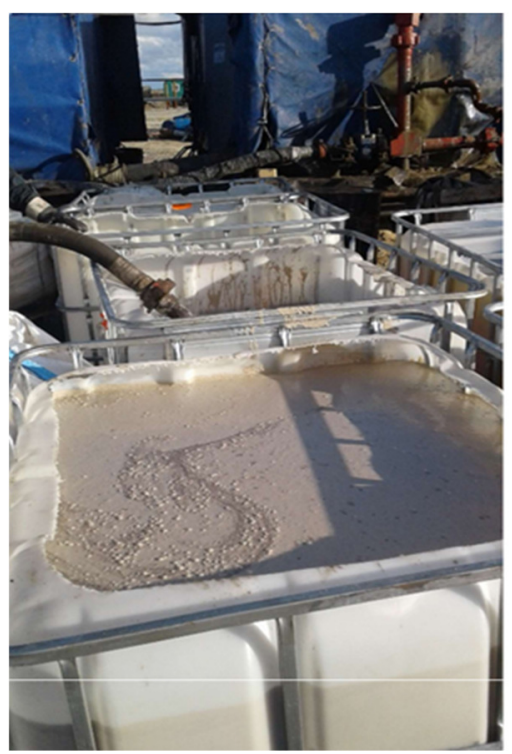

Fig. 1 Insulation composition base before addition of chrome acetate

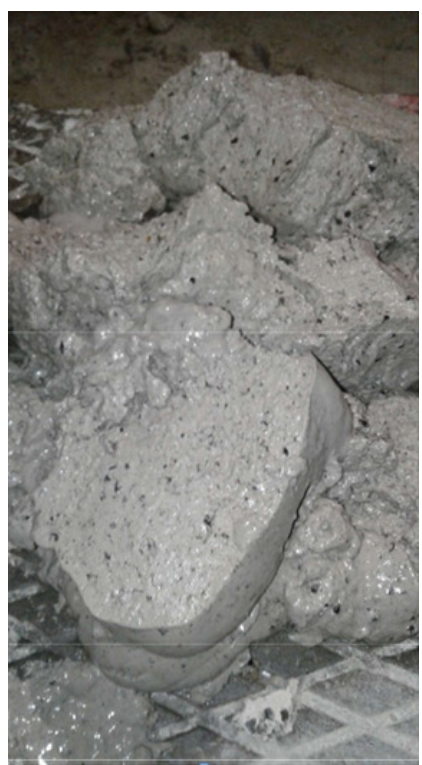

Fig. 2 Insulation composition sample after reacting 
RESULTS AND DISCUSSION - ECONOMIC ANALYSIS OF STUDIED METHODS

Expenses of cement plug installation

The data about calculation of the cost of cement plug are demonstrated in the Table 1.

Table 1 Calculation of the cost of a cement plug

\begin{tabular}{lccc}
\hline \multicolumn{1}{c}{ Indices } & $\begin{array}{c}\text { Quantity, } \\
\text { pcs }\end{array}$ & $\begin{array}{c}\text { Price, } \\
\text { thnd. y.e. }\end{array}$ & $\begin{array}{c}\text { Sum, } \\
\text { thnd. y.e. }\end{array}$ \\
\hline Cement plug & 1 & 200 & 200 \\
$\begin{array}{l}\text { Engineering support } \\
\text { for drill mud }\end{array}$ & 1 & 28 & 28 \\
Total & 2 & 228 & 228 \\
\hline
\end{tabular}

Cement plugging will take 48 hours.

Calculation of wages for a drilling shift for the time of the installation of a cement plug.

The data about calculation of wages for a drilling shift for the time of the installation of a cement plug are demonstrated in the Table 2.

Table 2

Calculation of wages for a drilling shift for the time of the installation of a cement plug

\begin{tabular}{|c|c|c|c|c|}
\hline Job title & 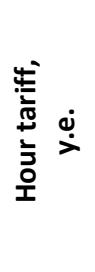 & نَّ & 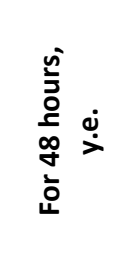 & 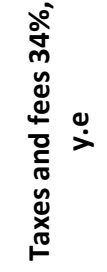 \\
\hline Driller of the 6 th rank & 130 & 171.6 & 8236,8 & 2800.5 \\
\hline $\begin{array}{l}\text { Assistant-driller } \\
\text { of the } 5 \text { th rank }\end{array}$ & 100 & 132 & 6336 & 2154.2 \\
\hline $\begin{array}{l}\text { Assistant-driller } \\
\text { of the } 5 \text { th rank }\end{array}$ & 100 & 132 & 6336 & 2154.2 \\
\hline $\begin{array}{l}\text { Assistant-driller } \\
\text { of the } 4 \text { th rank }\end{array}$ & 85 & 112.2 & 5385.6 & 1831.1 \\
\hline In total & & & 26294.4 & 8940 \\
\hline
\end{tabular}

Calculation of grouting machinery equipment.

To install a cement plug we will need three units of machinery: 1 mixer and 2 grout injection aggregates TSA 320.

Calculation of machinery cost for 24 hours of work:

The cost of each machinery unit is 800 y.e. per hour, consequently, the cost of machinery for 24 hours of work will be: $800 \cdot 24=19200$ y.e.

Total cost of the machinery equipment: $19200 \cdot 3=57600$ y.e.

All expenses for installation of a cement plug are in the Table 3.
Table 3

Expenses for installation of a cement plug

\begin{tabular}{lc}
\hline \multicolumn{1}{c}{ The name of an expense } & Measuring unit (thnd y.e.) \\
\hline Materials & 200 \\
Wages & 26.3 \\
Taxes and fees & 8.9 \\
Machinery & 57.6 \\
Outsource services & 28 \\
In total & 320.8 \\
\hline
\end{tabular}

Expenses for installation of insulation composition on the base of chrome acetate

The data about calculation of the cost of the installation of the insulation composition are demonstrated in the Table 4.

Table 4

Calculation of the cost of insulation composition on the base of chrome acetate

\begin{tabular}{lccc}
\hline \multicolumn{1}{c}{ Indices } & $\begin{array}{c}\text { Quantity, } \\
\text { pcs }\end{array}$ & $\begin{array}{c}\text { Price, } \\
\text { thnd. y.e. }\end{array}$ & $\begin{array}{c}\text { Sum, } \\
\text { thnd. y.e. }\end{array}$ \\
\hline $\begin{array}{l}\text { Insulation composition } \\
\text { on the base of chrome }\end{array}$ & 1 & 200 & 200 \\
$\begin{array}{l}\text { acetate } \\
\begin{array}{l}\text { Engineering support } \\
\text { for drill mud }\end{array}\end{array}$ & 1 & 28 & 28 \\
Total & 2 & 228 & 228 \\
\hline
\end{tabular}

For the installation of insulation composition on the base of chrome acetate 14 hours will be needed.

Calculation of wages for a drilling shift for the time of the installation of insulation composition on the base of chrome acetate

The data about the calculation of wages for a drilling shift for the time of the installation of insulation composition on the base of chrome acetate are demonstrated in Table 5.

Table 5

Calculation of wages for a drilling shift for the time of the installation of insulation composition on the base of chrome acetate

\begin{tabular}{|c|c|c|c|c|}
\hline Job title & 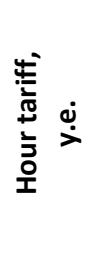 & 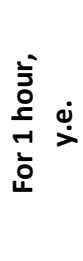 & 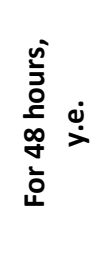 & 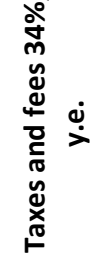 \\
\hline Driller of the 6 th rank & 130 & 171.6 & 2402.4 & 816.8 \\
\hline Assistant-driller of the 5 th rank & 100 & 132 & 1848 & 628.3 \\
\hline Assistant-driller of the 5 th rank & 100 & 132 & 1848 & 628.3 \\
\hline Assistant-driller of the 4 th rank & 85 & 112.2 & 1570.8 & 534.1 \\
\hline In total & & & 7669.2 & 2607.5 \\
\hline
\end{tabular}


Calculation of grouting machinery equipment.

To install an insulation composition on the base of chrome acetate we will need one unit of machinery: 1 grout injection aggregate TSA 320 . The aggregate work will take 4 hours

Calculation of machinery cost for 4 hours of work

The cost of machinery unit is 800 y.e. per hour, consequently, the cost of machinery for 4 hours of work will be: $800 \cdot 4=3200$ y.e.

All expenses for installation of an insulation composition on the base of chrome acetate are mentioned in the Table 6.

Table 6

Expenses for installation of an insulation composition on the base of chrome acetate

\begin{tabular}{lc}
\hline \multicolumn{1}{c}{ The name of an expense } & Measuring unit (thnd y.e.) \\
\hline Materials & 200 \\
Wages & 7.7 \\
Taxes and fees & 2.6 \\
Machinery & 3.2 \\
Outsource services & 28 \\
In total & 241.5 \\
\hline
\end{tabular}

Expenses for installation of QUICK-STONE ${ }^{\mathrm{TM}}$ composition The data about calculation of the cost of QUICK-STONE ${ }^{\mathrm{TM}}$ composition are demonstrated in the Table 7.

Table 7

Calculation of the cost of QUICK-STONE ${ }^{T M}$ composition

\begin{tabular}{lccc}
\hline \multicolumn{1}{c}{ Indices } & $\begin{array}{c}\text { Quantity, } \\
\text { pcs }\end{array}$ & $\begin{array}{c}\text { Price, thnd. } \\
\text { y.e. }\end{array}$ & $\begin{array}{c}\text { Sum, thnd. } \\
\text { y.e. }\end{array}$ \\
\hline QUICKSTONE $^{\mathrm{TM}}$ composition & 1 & 700 & 700 \\
$\begin{array}{l}\text { Engineering support for drill } \\
\text { mud }\end{array}$ & 1 & 28 & 28 \\
Total & 2 & 728 & 728 \\
\hline
\end{tabular}

For the installation of QUICK-STONE ${ }^{\mathrm{TM}}$ composition 18 hours will be needed.

Calculation of wages for a drilling shift for the time of the installation of QUICK-STONE ${ }^{\mathrm{TM}}$ composition.

The data about the calculation of wages for a drilling shift for the time of the installation of QUICK-STONE ${ }^{\text {TM }}$ Composition on the base of chrome acetate are demonstrated in Table 8

Table 8

Calculation of wages for a drilling shift for the time of the installation of QUICK-STONE ${ }^{T M}$ composition

\begin{tabular}{|c|c|c|c|c|}
\hline Job title & 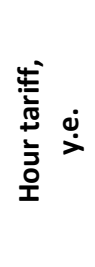 & 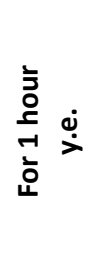 & 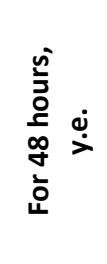 & 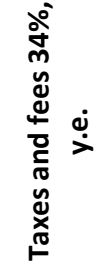 \\
\hline Driller of the 6 th rank & 130 & 171.6 & 3088.8 & 1050.2 \\
\hline Assistant-driller of the 5 th rank & 100 & 132 & 2376 & 807.8 \\
\hline Assistant-driller of the 5 th rank & 100 & 132 & 2376 & 807.8 \\
\hline $\begin{array}{l}\text { Assistant-driller of the } 4 \text { th rank } \\
\text { In total }\end{array}$ & 85 & 112.2 & $\begin{array}{l}2019.6 \\
9860.4\end{array}$ & $\begin{array}{r}686.6 \\
3352.5\end{array}$ \\
\hline
\end{tabular}

Calculation of grouting machinery equipment.

To install QUICK-STONE ${ }^{\mathrm{TM}}$ composition we will need two units of machinery: 1 grout injection aggregate TSA 320 and 1 mixing unit USO-20R1. The work of aggregates will take 18 hours.

Calculation of machinery cost for 18 hours of work

The cost of machinery unit is 800 y.e. per hour, consequently, the cost of machinery unit for 18 hours of work will be: $800 \cdot 18=14400$ y.e.

The cost of all grouting machinery: $14400 \cdot 2=28800$ y.e. All expenses for installation of QUICK-STONE ${ }^{\mathrm{TM}}$ composition on the base of chrome acetate are mentioned in the Table 9.

Table 9

Expenses for installation of QUICK-STONE ${ }^{T M}$ composition

\begin{tabular}{lc}
\hline \multicolumn{1}{c}{ The name of an expense } & Measuring unit (thnd y.e.) \\
\hline Materials & 700 \\
Wages & 9.9 \\
Taxes and fees & 3.4 \\
Machinery & 28.8 \\
Outsource services & 28 \\
In total & 770.1 \\
\hline
\end{tabular}

\section{CONCLUSION}

The comparative analysis of the use of QUICK-STONE ${ }^{\mathrm{TM}}$ composition, the insulation composition on the base of chrome acetate and cement plugging is shown in Table 10.

Table 10

Analysis of the use of QUICK-STONE ${ }^{\text {TM }}$ composition, insulation composition on the base of chrome acetate and cement plugging

\begin{tabular}{lccc}
\hline Teqnique & $\begin{array}{c}\text { Insulation composition } \\
\text { on the base of chrome } \\
\text { acetate }\end{array}$ & $\begin{array}{c}\text { QUICK- } \\
\text { STONE } \\
\text { composition }\end{array}$ & $\begin{array}{c}\text { Cement } \\
\text { plug }\end{array}$ \\
\hline $\begin{array}{c}\text { The name } \\
\text { of expenses }\end{array}$ & Measuring unit (thnd y.e.) & \\
Materials & 200 & 700 & 200 \\
Wages & 7.7 & 9.9 & 26.3 \\
Taxes and fees & 2.6 & 3.4 & 8.9 \\
Machinery & 3.2 & 28.8 & 57.6 \\
Outsource & 28 & 28 & 28 \\
services & 241.5 & 770.1 & 320.8 \\
In total & & & \\
\hline
\end{tabular}

On the base of the data from Table 10 we can make a conclusion, that the use of the insulation composition on the base of chrome acetate is preferred due to its economic efficiency: it is 3.2 times more beneficial than application of QUICK-STONE ${ }^{\mathrm{TM}}$ composition and 1.4 times more profitable than cement plugging.

Unlike the techniques, mentioned above, the use of insulation composition on the base of chrome acetate allows:

1) The use of the insulation composition on the chrome acetate base allows considerable reduction of time required to eliminate disastrous circulation loss without installation of cement plugs.

2) Avoiding BHA replacement.

3) Avoiding drilling-in after bullheading and overlapping of lost-circulation layer. 
4) Low cost, possibility of fast preparation, as it does not entail the delivery of additional chemicals, which also contributes to reduction of time required to eliminate disastrous circulation loss.

5) The use with every type of drilling mud (HBM, WBM) Basing on the positive experience of the use of this composition in the neighboring regions and considering its economic side, the technique can be used in regions of the Udmurt Republic.

\section{ACKNOWLEDGEMENTS}

This paper was financed from the resources of the Silesian University of Technology, project no. BK-235/ROZ-1/2020 (13/010/BK_20/0042).

\section{REFERENCES}

[1] O.V. Savenok, L.V. Povarova, G.V. Kusov "Application of superdeep drilling technology for study of the earth crust". IOP Conference Series: Earth and Environmental Science. 2020. C. 052066.

[2] L. Moroz, A. Uhrynovskyi, V. Popovych, B. Busko, G. Kogut "Effectiveness research of physical and chemical methods appfication for oil recovery enhancing using the asp for the strutynsky oil field conditions". Management Systems in Production Engineering, 2020, Vol. 28, Issue 2, pp. 104111. doi: $10.2478 / \mathrm{mspe}-2020-0016$

[3] V.A. Afanasyev "Optimization of well assemblies and well pump equipment of dual completion". Engineering Practice, no 2, p. 36, 2012.

[4] M.N. Baranov, P. Božek, V. Prajová, T.N. Ivanova, D.N. Novokshonov, A.I. Korshunov. "Constructing and calculating of multistage sucker rod string according to reduced stress". Acta Montanistica Slovaca, vol. 22, no. 2, pp. 107115, 2017.

[5] A. Dzhus, R. Rachkevych, A. Andrusyak, I. Rachkevych, O. Hryhoruk, S. Kasatkin "Evaluation the stress-strain state of pumping equipment in the curvilinear sections of the wells". Management Systems in Production Engineering, 2020, Vol. 28, Issue 3, pp. 189-195 doi: 10.2478/mspe2020-0028.

[6] A. Andrusyak, J. Grydzhuk, A. Dzhus, I. Steliga "Developing a method for the assessment of axial load in arbitrary cross-sections of the column of pumping rods". EasternEuropean Journal of Enterprise Technologies, vol. 1, no. 7, pp. 32-37, 2017. doi:10.15587/17294061.2017.92860.

[7] L.-M. Lao, H. Zhou "Application and effect of buoyancy on sucker rod string dynamics". Journal of Petroleum Science and Engineering, vol. 146, pp. 264-271, 2016. doi: 10.1016/j.petrol.2016.04.029.

[8] Q. Li, B. Chen, Z. Huang, H. Tang, G. Li, L. He, "Study on Equivalent Viscous Damping Coefficient of Sucker Rod Based on the Principle of Equal Friction Loss". Mathematical Problems in Engineering, vol. 2019, 2019. doi: 10.1155/2019/9272751.

[9] A. Velychkovych, I. Petryk, L. Ropyak "Analytical Study of Operational Properties of a Plate Shock Absorber of a Sucker-Rod String". Shock and Vibration, vol. 2020, article ID 3292713, 2020. doi: 10.1155/2020/3292713.

[10] D.Y. Wang, H.Z. Liu, "Dynamic modeling and analysis of sucker rod pumping system in a directional well". Lecture Notes in Electrical Engineering, vol. 408, pp. 1115-1127, 2017. doi: 10.1007/978-981-10-2875-5_90.
[11] M. Xing, S. Dong, "An improved longitudinal vibration model and dynamic characteristic of sucker rod string". Journal of Vibroengineering, vol. 16, no. 7, pp. 3432-3448, 2014.

[12] $Ł$. Bołoz "Interpretation of the results of mechanical rock properties testing with respect to mining methods". Acta Montanistica Slovaca, vol. 25, 1; pp. 81-93, 2020 doi: 10.46544/AMS.v25i1.8.

[13] X. Wang, D. Zhang, C. Sun, Y. Wang. "Surface subsidence control during bag filling mining of super high-water content material in the Handan mining area". International journal of oil gas and coal technology, Vol. 13, issue 1, p. 87-102, 2016. doi: 10.1504/IJOGCT.2016.078049.

[14] P. Strzałkowski, W. Piwowarski, R. Ścigała "The influence of extraction speed on the value of the coefficient of subsidence rate". Acta Montanistica Slovaca, vol. 24 number 4, pp. 331-341, 2019.

[15] M. Jami, A. Solgi, M. Pourkermani, Ali Asghar Moridi Farimani "GIS-based Analysis of Relative Tectonic Activity in Southeast of Iran with a focus on Taftan volcano". Acta Montanistica Slovaca, vol 24, number 4, pp. 351-365, 2019

[16] M.E. Qazizada, E. Pivarčiová "Reliability of parallel and serial centrifugal pumps for dewatering in mining process". Acta Montanistica Slovaca, vol 23, number 2, pp. 141-152, 2018.

[17] M.E. Qazizada, V. Sviatskii, P. Božek. "Analysis performance characteristics of centrifugal pump". MM Science Journal, 2016.

[18] T.N. Ivanova, P. Božek, A.I. Korshunov, V. Koretskiy “Analysis of distortion mechanisms used in rotary steerable systems". Multidisciplinary Aspects of Production Engineering - MAPE vol. 3, issue 1, pp. 331-346, 2020, doi:10.2478/mape-2020-0029.

[19] T. Liang, et al. "Identifying and evaluating surfactant additives to reduce water blocks after hydraulic fracturing for low permeability reservoirs". Presented at the SPE Improved for Oil Recovery Conference, Tulsa, SPE- 179601MS, 2016 . https://doi.org/10.2118/179601-MS .

[20] Q. Li, et al. "How extremely High-TDS produced water compositions affect selection of fracturing fluid additives". Presented at the SPE International Symposium on Oilfield Chemistry, The Woodlands, Texas, SPE-173746-MS, 2015. http://dx.doi.org/10.2118/173746-MS

[21] A. Raimbay, et al. "Effective of fracture roughness, shear displacement, fluid type, and proppant on the conductivity of a single fracture: a visual and quantitative analysis". Unconventional resources Conference Canada, pp. 446-470, 2017.

[22] C. Han, X. Ren, J. Zheng, "Analysis of abrasion for stator bushings of equal thickness screw pump in high temperature and sand crude oil". Zhongguo Jixie Gongcheng/China Mechanical Engineering, vol 28, Issue 4, 25, pp. 446-450, 2017.

[23] P. Rybár, L. Hvizdák, P. Hronček, M. Jesenský, R. Šimůnek "Computer modelling as a basic research and visualisation tool to research defunct historical mining technologies, using the example of cementation water mining in Smolník (Slovakia)". Acta Montanistica Slovaca, vol. 22, number 3, pp. 313-322, 2017.

[24] I. Stan-Kłeczek "The study of the elastic properties of carbonate rocks on a base of laboratory and field measurement". Acta Montanistica Slovaca, vol. 21, number 1, pp. 76-83, 2016. 
[25] P. Flegner, J. Kačur, M. Durdán, M. Laciak “Application of adaptive filters in rock separation by rotary drilling process identification". Acta Montanistica Slovaca, vol. 20, number 1, pp. 38-48, 2015.

[26] Z. Li, Itakura, K.-I., Ma, Y. "Survey of measurement-whiledrilling technology for small-diameter drilling machines". Electronic Journal of Geotechnical Engineering 19 (Z2). pp. 10267-10282, 2014.

[27] M.E. Qazizada, E. Pivarčiová, W. Bialy. Centrifugal pump characteristics computation and reliability evaluation at variable speed driven. ICCT: $5^{\text {th }}$ International Conference on Chemical Technology, Mikulov 2017. ISBN 978-8086238-62-3

\section{Tatiana Nikolaevna Ivanova}

ORCID ID: 0000-0003-2284-2949

Tchaikovsky Branch

"Perm National Research Polytechnic Institute", Russia

Federal State Budgetary Institution of Science

"Udmurt Federal Research Center of the Ural Branch

of the Russian Academy of Sciences",

Institute of Mechanics, Russia

e-mail: tatanic2013@yandex.ru

\section{Iwona Żabińska}

ORCID ID: 0000-0002-9368-4311

Silesian University of Technology

Faculty of Organization and Management

Institute of Economics and Informatics

ul. Roosevelta 26, 41-800 Zabrze, Poland

e-mail: Iwona.Zabinska@polsl.pl
[28] M.E. Qazizada, E. Pivarčiová, W. Bialy. Comparison of Gear and Peripheral pumps performance, evaluation of their reliability at operation region International Journal of Safety Science Vol. 01, No. 02, (2017), pp. 29-39 doi:10.24900/ijss/01024045.2017.0601

[29] T.N. Ivanova, A.I. Korshunov, M. Soldán, D.N. Novokshonov, W. Bialy, M.N. Baranov. The Efficiency of Use of Heating Cables in Wells of Complicated Stock. Acta Montanistica Slovaca. ISSN 1335-1788. Volume 23 (2018), number 2, pp. 153-162. 